\title{
Therapeutic options in the management of acromegaly: focus on lanreotide Autoge ${ }^{\circledR}$
}

\author{
Ferdinand Roelfsema \\ Nienke R Biermasz \\ Alberto M Pereira \\ Johannes A Romijn
}

Department of Endocrinology and Metabolism, Leiden University Medical Center, Leiden, The Netherlands
Correspondence: Ferdinand Roelfsema Department of Endocrinology and Metabolism, Leiden University Medical Center,Albinusdreef 2, 2333 ZA Leiden,

The Netherlands

Tel +3I 7I5263082

$\mathrm{Fax}+3 \mid 715248136$

Email f.roelfsema@lumc.nl
Background: In acromegaly, expert surgery is curative in only about $60 \%$ of patients. Postoperative radiation therapy is associated with a high incidence of hypopituitarism and its effect on growth hormone $(\mathrm{GH})$ production is slow, so that adjuvant medical treatment becomes of importance in the management of many patients.

Objective: To delineate the role of lanreotide in the treatment of acromegaly.

Methods: Search of Medline, Embase, and Web of Science databases for clinical studies of lanreotide in acromegaly.

Results: Treatment with lanreotide slow release and lanreotide Autogel ${ }^{\circledR}$ normalized GH and insulin-like growth factor-I (IGF-I) concentrations in about $50 \%$ of patients. The efficacy of $120 \mathrm{mg}$ lanreotide Autogel ${ }^{\circledR}$ on GH and IGF-I levels was comparable with that of $20 \mathrm{mg}$ octreotide LAR. There were no differences in improvement of cardiac function, decrease in pancreatic $\beta$-cell function, or occurrence of side effects, including cholelithiasis, between octreotide LAR and lanreotide Autogel ${ }^{\circledR}$. When postoperative treatment with somatostatin analogs does not result in normalization of serum IGF-I and GH levels after noncurative surgery, pegvisomant alone or in combination with somatostatin analogs can control these levels in a substantial number of patients.

Keywords: acromegaly, lanreotide, somatostatin analog, growth hormone, pegvisomant

\section{Introduction}

Growth hormone (GH), a polypeptide consisting of 191 amino acids and which is secreted by the pituitary gland, has a multitude of effects. The most obvious effect is the stimulation of growth in prepubertal and pubertal children. In childhood, lack of this hormone leads to dwarfism and excessive secretion results in gigantism. Growth hormone has profound metabolic effects by stimulating protein anabolism and lipolysis. Other effects include stimulation of bone turnover, leading to a net increase in bone volume, muscle growth, insulin antagonism, renal sodium retention, and immuno modulation. Most of the effects of GH are indirectly mediated via insulin-like growth factor-I (IGF-I). IGF-I is a peptide synthesized and secreted as a result of GH-signaling, which acts locally in an autocrine or paracrine manner, or systematically as a hormone when secreted by the liver (Le Roith et al 2001). The liver secretes about $70 \%$ of the total circulating IGF-I in mice (Sjogren et al 1999).

Excessive secretion of GH leads to acromegaly, a disfiguring and debilitating condition causing severe co-morbidity and premature death (Wright et al 1970; Ezzat et al 1994; Melmed 2006; Ben-Shlomo and Melmed 2008).

The purpose of this review is to establish the role of lanreotide, particularly lanreotide Autogel ${ }^{\circledR}$, in the management of acromegaly based on published data. It is appropriate, however, to outline first the clinical features of acromegaly and to discuss therapeutic approaches in its management. 


\section{Acromegaly}

Acromegaly is a rare disease, caused by a GH-secreting adenoma and in even more seldom instances (about 1\%) due to excessive GHRH secretion, usually by a carcinoid tumor of the lung or gastrointestinal tract (Biermasz et al 2007). The incidence of acromegaly is about 3-4 per 1 million per year and the prevalence is $60-70$ per 1 million, without geographical or sex differences (Alexander et al 1980 Bengtsson et al 1988; Ritchie et al 1990; Mestron et al 2004). Clinical features of acromegaly include acral enlargement, prognatism, jaw malocclusion, arthropathy, carpal tunnel syndrome, hyperhydrosis, sleep apnea, and visceromegaly (Colao et al 2004; Melmed 2006). Acromegaly is also associated with increased cardiovascular morbidity and mortality. Active disease leads to a specific form of cardiomyopathy which involves myocardium, conduction system, and heart valves. Clinical manifestations include arrhythmias, valvular regurgitation, concentric left ventricular hypertrophy, and left ventricular systolic and diastolic dysfunction (Clayton 2003; Colao et al 2004; Pereira et al 2004). The incidence of hypertension and of decreased glucose tolerance is also increased. This is also true for the incidence of colon polyps and colon carcinoma (Orme et al 1998; Renehan and Shalet 2002). It is controversial, however, whether the relative risk of cancer is increased in patients with acromegaly compared with that of the general population (Jenkins and Besser 2001; Melmed 2001; Loeper and Ezzat 2008).

Local tumoral symptoms include chronic headache, visual field defects, and rarely cranial nerve palsies. Hypopituitarism is mostly associated with large tumors with a generally low incidence in patients with acromegaly varying from $3 \%$ to $10 \%$ (Greenman et al 1995).

The increased standardized mortality rate (SMR) decreased from 3-fold in older series to 1.3-fold in series with predominantly primary transsphenoidal surgery (Swaeringen et al 1998; Holdaway et al 2004; Kauppinen et al 2005; Holdaway 2007; Dekkers et al 2008). Reported risk factors include diabetes mellitus, cardiomyopathy, sleep apnea, and cerebrovascular events and in some, but not all, studies also pituitary irradiation (Ayuk et al 2004; Biermasz et al 2004a; Kauppinen et al 2005). The decrease in mortality observed in acromegaly is likely to be due to the introduction of effective therapies such as transsphenoidal surgery in the 1970s and to postoperative radiotherapy, leading to normalization of GH and IGF-I concentrations in a substantial number of patients. The effective treatment of systemic co-morbidities also plays a role in the observed decrease in mortality. Only few patients using adjuvant somatostatin analogs are included in mortality series and it is of note that at present no mortality data exist for primary medical treatment including pegvisomant treatment. Most studies have suggested that a lower $\mathrm{GH}$, for example below $2.5 \mu \mathrm{g} / \mathrm{L}$, is associated with improved and even normal survival. In some but not all studies normal IGF-I was also associated with improved mortality (Ayuk et al 2004; Biermasz et al 2004a; Holdaway et al 2004; Kauppinen et al 2005). Discrepancies between studies may be explained by a single GH or IGF-I measurement being used in most studies, which is hardly representative for disease status in the entire follow-up period; by the unavailability of IGF-I in a substantial number of patients; and by GH and IGF-I assay differences. In addition, individual mortality studies consist of relatively small numbers of patients with large confidence intervals including 1.0, limiting statistical power.

In acromegaly detailed studies of spontaneous GH secretion have demonstrated increased pulsatility (increased pulse frequency), amplified burst mass, and increased basal secretion, associated with decreased regularity (Barkan et al 1989; Ho et al 1994; van den Berg et al 1994). Biochemical criteria of active disease and remission are the (mean) GH level, glucose-suppressed GH concentration, and the IGF-I level (Giustina et al 2000). GH assays differ in specificity, sensitivity, and GH standard, and therefore individual clinical endocrine laboratories should establish normal ranges of gender- and age-related GH and IGF-I values and ideally corrected for fat mass or a fat mass-derived parameter (Gullu et al 2004; Bidlingmaier and Strasburger 2007). Circulating IGF-I reflects GH secretion rate and serum concentrations of IGF-I are elevated in all patients with active disease (Melmed 2006). IGF-I concentrations decrease with advancing age. In addition, gender, sex hormone status, the use of oral estrogens, thyroxin, and body composition can all influence IGF-I concentrations (Clemmons 2007).

\section{Treatment of acromegaly}

As discussed above, epidemiological studies have clearly demonstrated that controlling GH and IGF-I secretion is the most significant determinant of restoring survival in patients with acromegaly The main goal of treatment of acromegaly is therefore to achieve GH levels of less than $1 \mu \mathrm{g} / \mathrm{L}$ after a glucose load, to normalize age- and gender-matched IGF-I levels, to ablate or reduce tumor mass and prevent its recurrence, and to alleviate significant co-morbidities, especially cardiovascular, pulmonary, and metabolic disturbances (Melmed et al 2002). The currently available treatment modalities for acromegaly are selective transsphenoidal adenomectomy, radiotherapy, medical treatment, or combinations thereof. 


\section{Transsphenoidal surgery}

This oldest treatment modality was developed a century ago by the Austrian neurosurgeon Schloffer (Schloffer 1907). It is generally performed via the transnasal, transsphenoidal route and is associated with low morbidity and mortality. In recent years most neurosurgeons have adopted the endoscope in lieu of the surgical microscope, which has obvious advantages for the patient and also leads to better visualization of the operating field. Other variants of surgical techniques are neuronavigating and real-time intraoperative MRI scanning, aimed at visualization of tiny tumor remnants after resection of the adenoma (Fahlbusch et al 2005; Thomale et al 2005). GH secretion pattern is restored when the adenoma is completely removed (van den Berg et al 1998). Surgical cure is highest in patients with a microadenoma (diameter less than $10 \mathrm{~mm}$ ) varying from $80 \%$ to more than $90 \%$ in the hands of experienced neurosurgeons. However, complete tumor removal becomes more difficult with increasing size of the tumor and expansion into the neighboring delicate structures, and the cure rate of large macroadenoma drops to only $20 \%-40 \%$ of cases (Freda et al 1998; Biermasz et al 2000a; Kaltsas et al 2001; Kreutzer et al 2001; Shimon et al 2001; Beauregard et al 2003; De et al 2003; Nomikos et al 2005; Lüdecke and Abe 2006). The obvious advantage of successful surgery is the rapid normalization of GH secretion and decrease in IGFI levels, while the complication of (partial) hypopituitarism is generally below $10 \%$ (Nomikos et al 2005; Lüdecke and Abe 2006). Second surgical procedures are generally safe but less successful than primary surgery (Long et al 1996). The experience of the neurosurgeon is critical for a high cure rate (Ahmed et al 1999; Bates et al 2008).

\section{Radiotherapy}

Conventional radiotherapy is administered by a linear accelerator (4-8 MeV) with a total dose of 40-45 Gy, fractionated in at least 20 sessions. A rotational field, 2 opposing fields, or a 3 -field technique are used. A mean GH decrease of about $50 \%$ is observed in the first 2 years after irradiation and after 5 years a $75 \%$ decline is reported (Biermasz et al 2000b; Wass et al 2003). Whether the GH level normalizes post irradiation mainly depends on pre-irradiation serum GH concentration and the time interval between radiotherapy and the measurement of GH and IGF-1 levels. Post-irradiation remission rates are, however, largely affected by the extent of surgical debulking prior to radiotherapy. Other than the slow onset of GH control another drawback is the increasing incidence of hypopituitarism varying from $50 \%-85 \%$ after a follow-up of 10 years or longer (Minniti et al 2005; Biermasz et al 2006).
Barkan and colleagues were the first to question the efficacy of radiotherapy in normalizing serum IGF-I concentrations, with many studies addressing the effects of conventional pituitary irradiation on IGF-I and strict GH criteria being reported thereafter (Barkan et al 1997). A few reports supported an apparent lack of efficacy of pituitary irradiation (Thalassinos et al 1998; Cozzi et al 2001), whereas others reported normalization of IGF-I in 44\%-79\% of patients after 5-15 years of follow-up (Ciccarelli et al 1993; Barrande et al 2000; Powell et al 2000; Epaminonda et al 2001; Minniti et al 2005).

Another radiation technique is radiosurgery, which is the precise, stereotactic delivery of a single high radiation dose to a defined target with a steep dose gradient at the tumor margin (Mahmoud Ahmed et al 2001; Castinetti et al 2005; Roberts et al 2007). This form of radiotherapy is performed using a gamma knife with up to $200{ }^{60} \mathrm{Co}$ sources, a Linac-based system, or proton beams (Marcou and Plowman 2000; Brada et al 2004; Sheehan et al 2005). The perceived advantage of this form of irradiation is that only one session is required. There is otherwise no convincing evidence as yet that radiosurgery is superior to conventional irradiation in terms of GH control, time needed to reach clinically acceptable GH levels, and incidence of hypopituitarism (Landolt et al 1998; Attanasio et al 2003a; Biermasz et al 2006).

Disadvantages of pituitary irradiation other than the development of hypopituitarism include decreased quality of life (QoL), the development of secondary tumors, cerebrovascular disease, and increased mortality. In one cross-sectional study, decreased health-related QoL was described in acromegalic patients in longterm remission (Biermasz et al 2004b). These data were confirmed by another QoL analysis of treated acromegalic patients (Rowles et al 2005). A significant predictor of poor QoL was radiotherapy, but the pathophysiologic mechanism remains unclear. Increased mortality due to cerebrovascular disease was observed in two of the studies (Ayuk et al 2004; Kauppinen et al 2005) but not in the other three (Bates et al 1993; Ahmed et al 1999; Biermasz et al 2004a).The effect of radiotherapy on mortality is thus as yet to be established. The likelihood of secondary tumor formation after pituitary irradiation is very low (Brada et al 1992).

\section{Medical treatment}

The three most important drugs used for medical treatment of acromegaly are dopamine agonists, somatostatin analogs, and GH-receptor modulating chemicals. 


\section{Dopamine agonists}

Bromocriptine, a dopamine agonist, effectively reduces GH secretion in only a minority of GH-secreting adenoma (Jaffe and Barkan 1992). Cabergoline, a more potent dopamine agonist with prolonged duration of action, was reported to normalize GH in 35\% and IGF-I in 44\% of 46 patients with a purely GH-secreting adenoma when given at a dose of $1-1.75 \mathrm{mg} /$ week (Abs et al 1998). The efficacy of cabergoline was somewhat better in tumors co-secreting prolactin. Quinagolide, another dopamine agonist, was reported to normalize IGF-I in $28 \%$ of patients (Freda 2003). Most endocrinologists use long-acting dopamine agonists as adjunct therapy in patients who fail to normalize GH secretion with octreotide monotherapy. The combination therapy normalizes serum IGF-I concentrations in $30 \%-40 \%$ of patients, irrespective of the prolactin concentration (Cozzi et al 2004). Side effects of cabergoline are rare although there has been recent concern about cardiac valve hypertrophy, as observed in patients with Parkinson's disease. Whereas the dose in Parkinson's disease is generally much higher than that used for endocrine indications (Schade et al 2007), patients with acromegaly generally require long-term medical treatment for GH control. The use of dopaminergic drugs other than cabergoline is probably safer in acromegaly.

\section{Somatostatin analogs}

Somatostatin was isolated in 1973 from the hypothalamus and subsequently synthesized (Brazeau et al 1973). The hormone is processed from a large pre-prohormone into 2 cyclic peptides, consisting of 14 or 28 amino acids. The short form, $\mathrm{SS} 14$, is predominantly present in the brain, whereas SS28 is widely distributed in peripheral organs. Somatostatin acts as neuromodulator and neurotransmitter in the brain and as a neurohormone in the regulation of GH and thyroidstimulating hormone secretion. In addition, somatostatin inhibits tumoral adrenocorticotropic hormone secretion in Cushing's disease (van der Hoek et al 2004). Somatostatin acts as neurotransmitter in the extensive myo-enteric plexus, and as hormone in a paracrine and autocrine fashion. Via specific receptors, somatostatin exerts many inhibitory effects on gut and pancreatic hormones, including gastrin, insulin, glucagon, vasoactive intestinal peptide, motilin, and gastric inhibitory polypeptide. Other effects of somatostatin include inhibition of gastric emptying, pancreatic enzymes and bicarbonate secretion, gastrointestinal blood flow and bile flow (Brazeau et al 1973; Reichlin 1983; Patel 1999). Somatostatin acts via a G-protein-coupled receptor, of which 5 subtypes have been cloned and characterized (Lamberts et al 1996).
After binding of somatostatin to its receptor, the activities of adenyl cyclase and of calcium channels are inhibited, whereas phosphotyrosine phosphatase activity and mitogen-activated protein kinases activity are stimulated. The first two processes are involved in the inhibition of secretory processes, and the latter two may play a role in cell proliferation, eg, activation of the SST3 receptor may induce apoptosis (Danilla et al 2001; Bevan 2005). Analogs of somatostatin differ in binding properties to different receptor subtypes (Lamberts et al 1996). Many benign and malign tumors express one or more somatostatin receptors. Receptor distribution and density and homogeneity of receptor expression within the tumor determine whether a particular analog can be effectively used therapeutically (Krantic et al 2004; Olias et al 2004).

GH-secreting pituitary adenomas express predominantly SST2 and SST5 receptors. The current clinically used analogs, octreotide and lanreotide, inhibit GH secretion via the somatostatin receptor subtypes 2 and 5 (Hofland and Lamberts 2003). The plasma half-life of these analogs is about 20 times longer than that of native somatostatin, which is less than 3 minutes (Lamberts et al 1996). Although the most important effect of somatostatin analogs is the inhibition of GH secretion by the adenoma leading to a subsequent decrease in circulating liver-derived IGF-I, part of the peripheral effects of these analogs is caused by the direct inhibition of IGF-I gene transcription after binding to the somatostatin receptor (Serri et al 1992; Murray et al 2004). The magnitude of this latter effect in various organs is not exactly known.

\section{GH receptor antagonists}

Pegvisomant is an engineered GH analog that antagonizes $\mathrm{GH}$ at the receptor site, and thus prevents endogenous GH activation of its receptor and subsequent downstream signaling. In short-term studies, the lowest dose $(10 \mathrm{mg} /$ day $)$ normalized IGF-I in $38 \%$ of the patients and $20 \mathrm{mg}$ normalized IGF-I in $82 \%$ of patients (Trainer et al 2000; van der Lely et al 2001). In a minority of patients ( 2 out of 112 and 7 out of 229 patients, respectively) adenoma size increased during a relatively short treatment period (van der Lely et al 2001; Schreiber et al 2007). Careful documentation of tumor size before starting pegvisomant treatment is therefore compulsory and long-term monitoring is advisable. A small number of patients (2 out of 167 cases) developed abnormalities in liver function tests, necessitating withdrawal of the drug, although increased liver enzyme levels, ie, more than 3 times the upper level of normal, was observed in $5.5 \%$ of 229 patients, normalizing spontaneously in $3.1 \%$ 
on continuing treatment (van der Lely et al 2001; Schreiber et al 2007). About $40 \%$ of patients develop minor abnormalities in liver function tests on combined treatment with somatostatin analogs, which do not requiring stopping of the drug and which usually resolve spontaneously (Feenstra et al 2005).

\section{Pharmokinetics of lanreotide}

The first pharmaceutical available form of lanreotide (BIM 23014) was relatively short-acting, requiring multiple dosing, 3 times a day, or subcutaneous infusion. This was nevertheless a major advance in the treatment of many patients who had already undergone unsuccessful surgery and pituitary irradiation and for whom there were no other treatment options (Figure 1). In healthy subjects, maximal serum concentrations of lanreotide were reached after $30 \mathrm{~min}$ and the serum half-life was $90 \mathrm{~min}, 30$ times greater than that of native somatostatin (Kuhn et al 1994; Antonijoan et al 2004; Table 1). Subsequently, a long-acting form of lanreotide was developed by incorporating the drug into polyactide - polyglycolide microspheres, so that the half-life was considerably prolonged, and the injection interval could be extended to 7-14 days (Heron et al 1993). The lanreotide release pattern from the long-acting form is biphasic, ie, an early release during 2 days from the drug adsorbed onto the surface of the

SS14
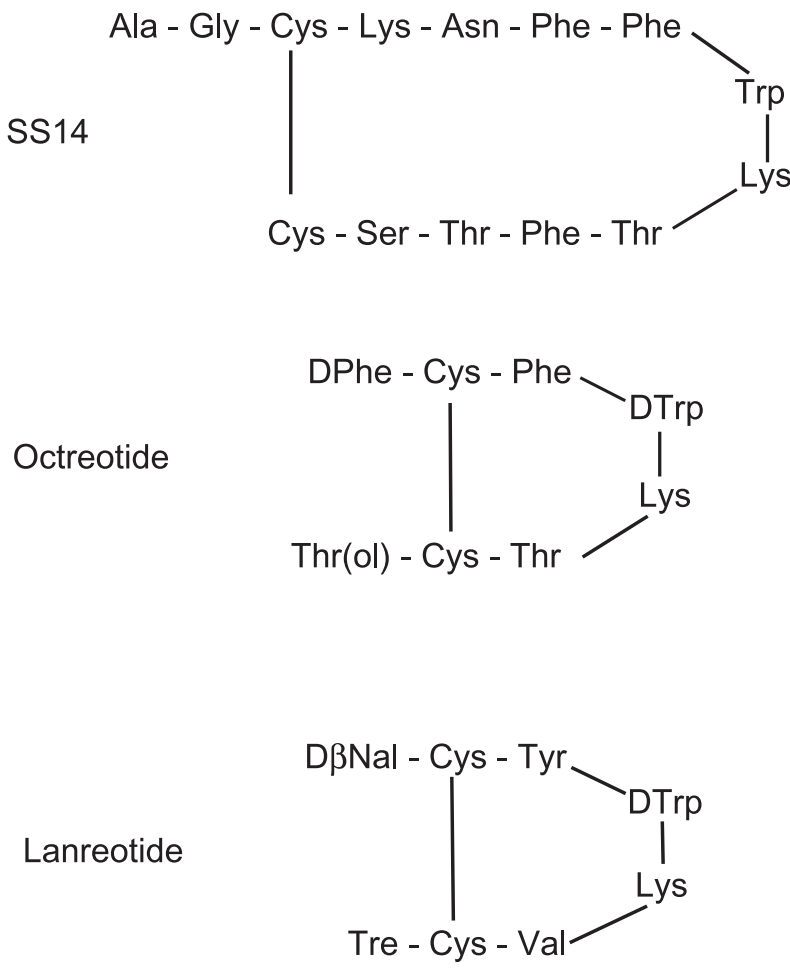

Figure I Amino acid structure of somatostatin- I4, octreotide. and lanreotide. microspheres, followed by sustained release for about 1 week, starting at day 4, as a result of enzymatic breakdown of the microspheres, followed again by an exponential decrease in drug release. It was subsequently discovered that lanreotide had the unique property of self aggregation under favorable conditions, leading to a stable structure of highly organized nanotubules (Valery et al 2003, 2008). This formulation of the drug was named lanreotide Autogel ${ }^{\circledR}$ and has a long halflife after subcutaneous injection determined by pseudo-first order kinetics. Maximal serum concentrations are reached after 1-2 days (see Table 1) in healthy subjects and the serum half-life amounts to 25.5 days (Antonijoan et al 2004; Astruc et al 2005). In acromegalic patients maximal values are reached after 3.8-7.7 days under steady state conditions, depending on the dose administered (Table 2). Simulated steady state pharmacokinetic profiles of long-acting octreotide and lanreotide Autoge ${ }^{\circledR}$ differ significantly (Astruc et al 2005; Bronstein et al 2005). During long-acting octreotide treatment, serum concentrations of the drug are more or less stable, whereas the characteristic first-order kinetics of lanreotide Autogel ${ }^{\circledR}$ is superimposed on levels just before the next administration (see Figure 2; Astruc et al 2005). The pharmacokinetic differences therefore indicate that octreotide LAR can be better tailored to therapeutic levels, whereas serum levels of lanreotide must be (too) high for part of the interval between injections in order to be effective in the period before the next administration. The possible clinical consequence(s) of these different pharmacokinetic profiles can be resolved only in long-term studies in which lanreotide Autogel ${ }^{\circledR}$ is compared with octreotide or drugs with a similar pharmacokinetic profile.

\section{Efficacy of lanreotide}

The first studies with lanreotide were performed using lanreotide Slow Release (lanreotide SR). The drug was first available in vials containing $30 \mathrm{mg}$, to be injected at 2-weekly intervals. The interval was shortened, however, to 7-10 days when GH was insufficiently suppressed. The drug later also became available in vials containing $60 \mathrm{mg}$ of lanreotide so that the injection interval could be extended to 4 weeks, similar to that of the long established octreotide LAR. Studies using lanreotide SR $30 \mathrm{mg}$ and lanreotide SR $60 \mathrm{mg}$ are summarized in Table 3. Most patients had undergone pituitary surgery and many were irradiated, either as primary treatment (a minority) or as adjuvant treatment after noncurative surgery. In addition, in almost all studies patients had been treated with octreotide. Normal mean GH concentration, as defined by the authors (generally below 
Table I Pharmacokinetic analysis of a single subcutaneous dose of short-acting lanreotide and lanreotide Autogel ${ }^{\circledR}$ in healthy subjects

\begin{tabular}{|c|c|c|c|c|}
\hline & $\begin{array}{l}\text { Short-acting lanreotide } \\
n=24\end{array}$ & $\begin{array}{l}\text { lanreotide Autogel } \\
n=24\end{array}$ & $\begin{array}{l}\text { lanreotide Autoge }{ }^{b} \\
n=10\end{array}$ & $\begin{array}{l}\text { lanreotide Autogel }{ }^{b} \\
n=10\end{array}$ \\
\hline Dose & $7 \mu g / \mathrm{kg}$ & $60 \mathrm{mg}$ & $90 \mathrm{mg}$ & $120 \mathrm{mg}$ \\
\hline $\mathrm{C}_{\max }$ & $7.98 \mathrm{ng} / \mathrm{mL}$ & $5.71 \mathrm{ng} / \mathrm{mL}$ & $6.7 \mathrm{ng} / \mathrm{mL}$ & \\
\hline $\mathrm{T}_{\max }$ & $0.43 \mathrm{~h}$ & 0.38 day & 2.4 day & I.I day \\
\hline Half-life & $\mathrm{I} .74 \mathrm{~h}$ & 22 days & 25.5 day & \\
\hline AUC & I6.5I ng.mL $\mathrm{m}^{-1} \cdot \mathrm{h}$ & 79.48 ng.mL $L^{-1}$.day & I I6 ng.mL $\mathrm{mL}^{-1}$.day & I 33 ng.mL $L^{-1}$.day \\
\hline MRT & $1.95 \mathrm{~h}$ & 31.97 days & & \\
\hline
\end{tabular}

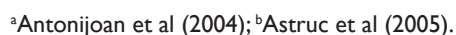

Abbreviations: AUC, area under the curve; MRT, mean residence time.

$2.5 \mu \mathrm{g} / \mathrm{L})$ was achieved in $23 \%-93 \%$ of the cases treated with lanreotide SR $30 \mathrm{mg}$, and in $25 \%-65 \%$ of the cases treated with lanreotide $60 \mathrm{mg}$. Normal values of IGF-I were obtained in $23 \%-68 \%$ of patients on lanreotide SR $30 \mathrm{mg}$, and $35 \%-62 \%$ of these on lanreotide SR $60 \mathrm{mg}$. The weighted means of normalization of GH and of IGF-I were $54 \%$ and $49 \%$, respectively, during treatment with $30 \mathrm{mg}$ lanreotide, whereas during treatment with lanreotide SR $60 \mathrm{mg}$ these values were $60 \%$ and $58 \%$.

Comparative studies of efficacy between octreotide and lanreotide are summarized in Table 4. Short-acting octreotide, mostly given 3 times a day, had a similar GH-suppressive effect as lanreotide SR. Normal GH was obtained in $52 \%$ and $49 \%$ of a total of 218 patients, but normalized IGF-I was more frequently found in patients treated with lanreotide SR $30 \mathrm{mg} / 10-14$ days, ie, $49 \%$ versus $64 \%$. The efficacy of octreotide LAR was slightly higher than that of lanreotide SR: normalized GH and IGF-I were obtained in $64 \%$ and $62 \%$ of 155 patients treated with octreotide LAR versus $52 \%$ and $50 \%$, respectively, in the same patients during treatment with lanreotide SR. A limitation of all these studies, with one exception, is that they were not randomized. The overall better efficacy of octreotide LAR compared with lanreotide SR agrees with findings from a recent meta-analysis (Freda et al 2005).

Table 2 Pharmacokinetics of lanreotide Autoge ${ }^{\circledR}$ during steady state conditions in patients with acromegaly

\begin{tabular}{llll}
\hline Dose & $\mathbf{6 0} \mathbf{~ m g}$ & $\mathbf{9 0} \mathbf{~ m g}$ & $\mathbf{1 2 0 ~ \mathbf { ~ m }}$ \\
\hline $\mathrm{T}_{\text {max }}($ days $)$ & 85 & 84 & 85 \\
$\mathrm{C}_{\text {mean }}(\mathrm{ng} / \mathrm{mL})$ & 2.46 & 3.04 & 4.52 \\
$\mathrm{C}_{\text {min }}(\mathrm{ng} / \mathrm{mL})$ & 1,82 & 2.51 & 3.76 \\
$\mathrm{C}_{\text {max }}(\mathrm{ng} / \mathrm{mL})$ & 3.82 & 5.69 & 7.69 \\
$\mathrm{AUC}\left(\mathrm{ng} \cdot \mathrm{mL}^{-1}\right.$. day & 68.8 & 85.1 & 127 \\
\hline
\end{tabular}

From data of Bronstein et al (2005).

Abbreviation: $A \cup C$, area under the curve.
Lanreotide Autogel ${ }^{\circledR}$ was introduced about 8 years ago, and the first report in the English literature was published in 2002. Clinical efficacy studies are summarized in Table 5. Most of the patients who took part in these studies had undergone pituitary surgery, often with adjuvant irradiation, and almost all patients were on octreotide or lanreotide SR treatment, while a minority also used dopaminergic drugs. The results of these studies should therefore be considered critically, as a selection bias cannot be excluded. Normal GH, defined as a concentration below $2.5 \mu \mathrm{g} / \mathrm{L}$ in fasting single blood samples or as the mean of serial samples was observed in $38 \%-80 \%$ of cases and normal age-related IGF-I was recorded in $39 \%-80 \%$ of patients on lanreotide Autogel ${ }^{\circledR}$. In these studies the weighted mean for GH normalization was $58 \%$ and for IGF-I $48 \%$ in a population of 370 patients. The results mentioned above refer to measurements at the end of the study when dose titration of lanreotide Autogel ${ }^{\circledR}$ was fully effective. Indeed, most of the patients ended receiving the highest dose of $120 \mathrm{mg}$. These results do not differ from

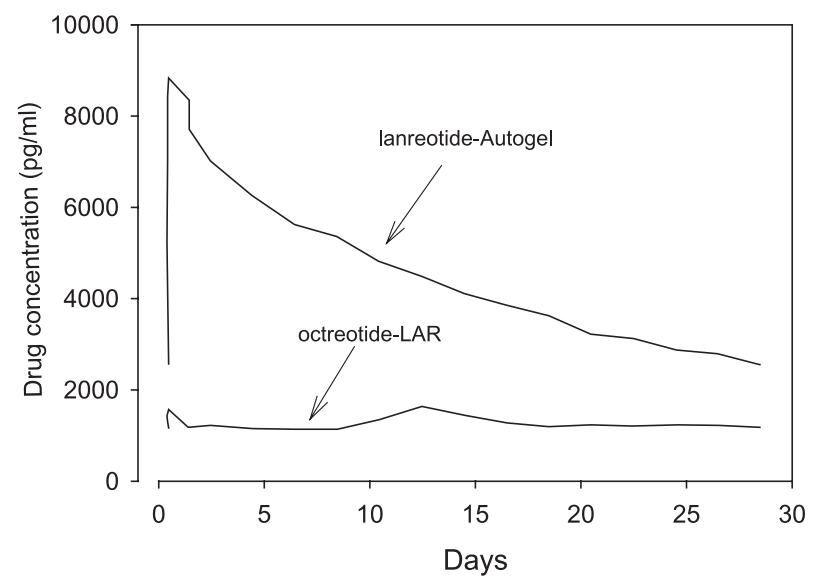

Figure 2 Pharmacokinetic profiles of lanreotide Autoge ${ }^{\circledR}(90 \mathrm{mg})$ and octreotideLAR $(20 \mathrm{mg})$ at steady state.The lines represent mean values of 10 simulated profiles. From data of Astruc et al (2005). 


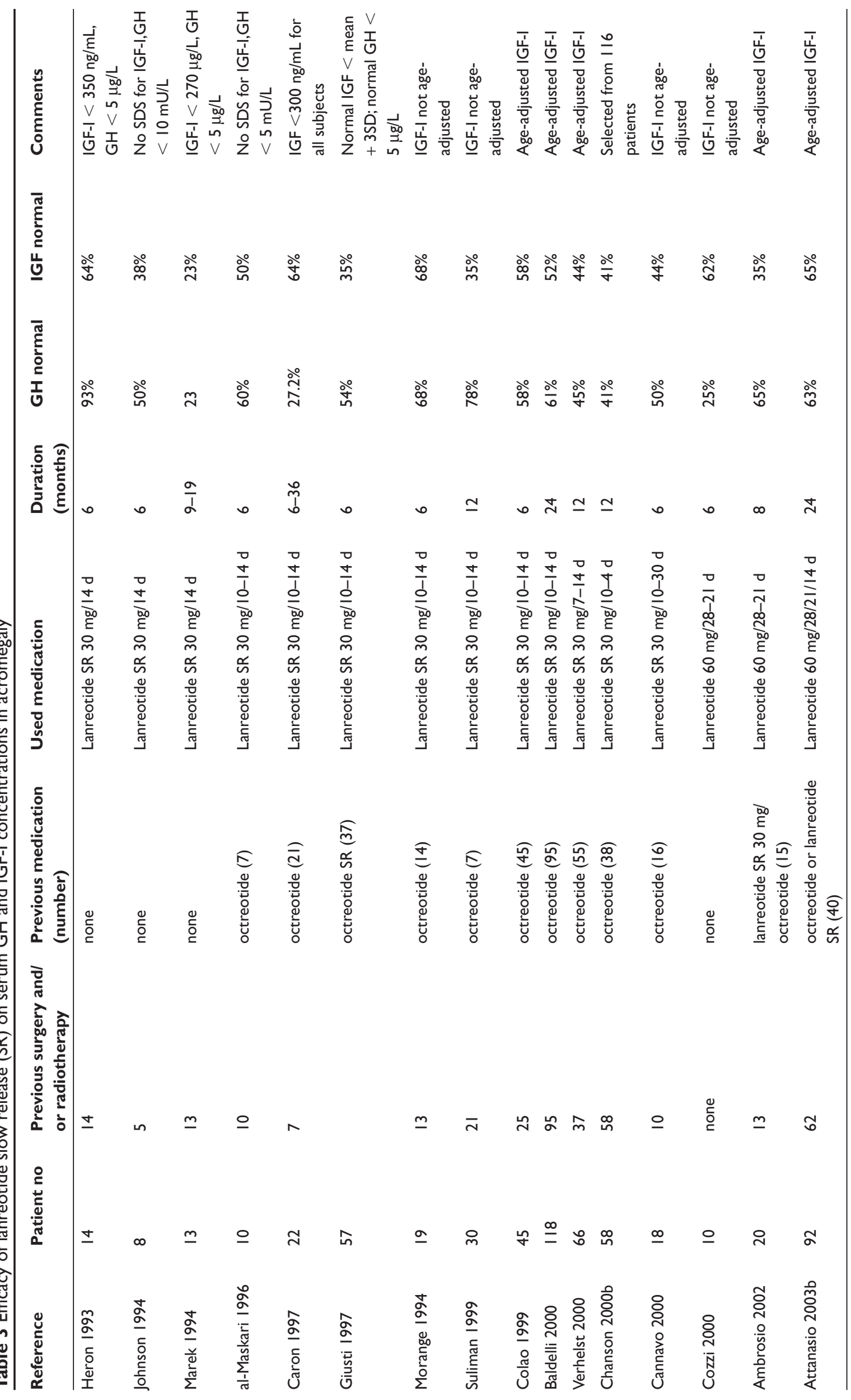



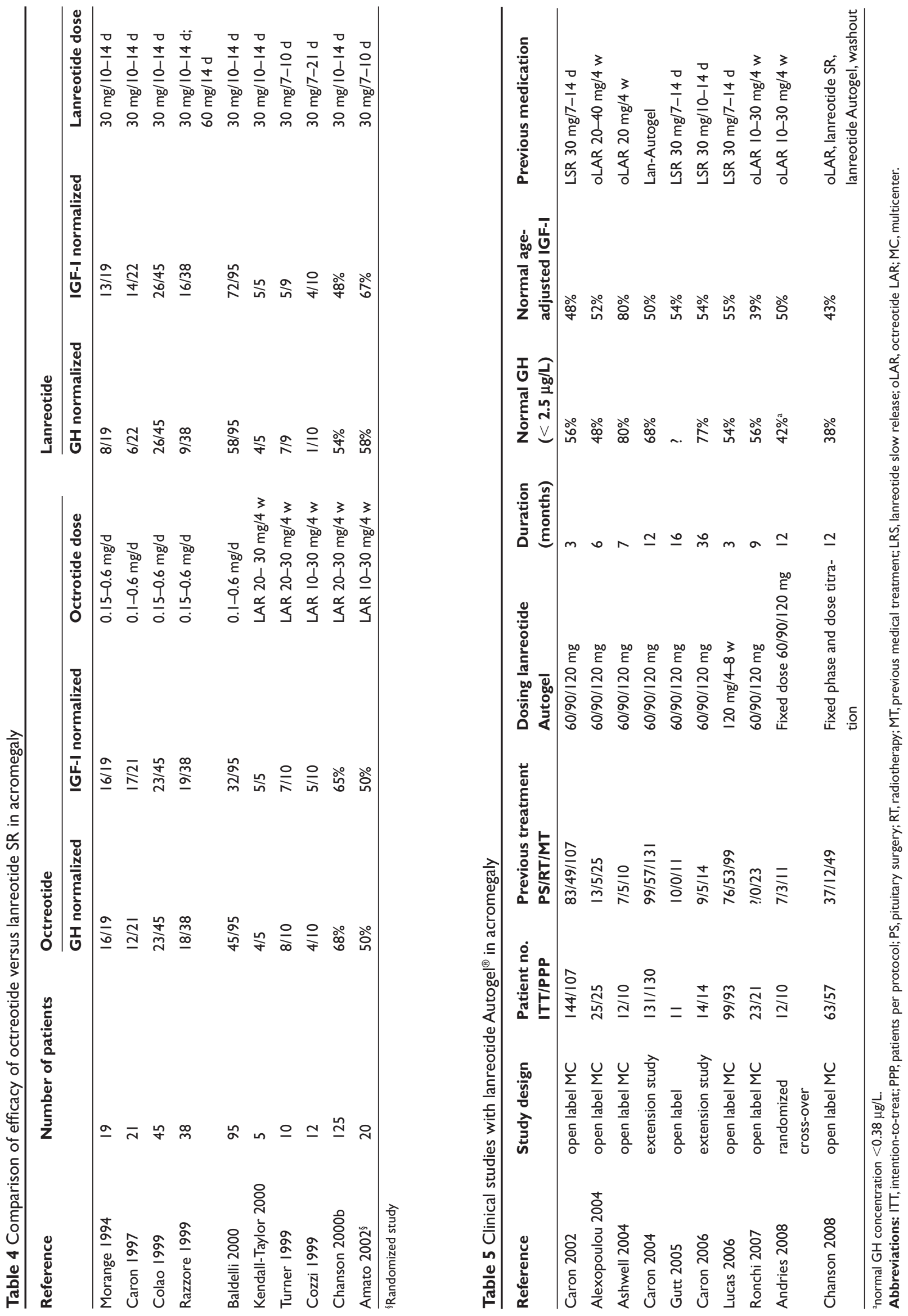
data obtained in patients on lanreotide SR (see above). Part of these studies compared the efficacy of octreotide LAR and lanreotide Autogel ${ }^{\circledR}$. A drawback of these studies is that with the exception of one study none were randomized (Andries et al 2008). An open-label, uncontrolled, single-group assignment study on the effects of lanreotide Autoge $l^{\circledR}$ in 27 previously untreated patients with acromegaly was recently completed (ClinicalTrial.gov NCT00627796). Although the study is rather small it will contribute further data on IGF-I control and tumor reduction.

In a 3-month study in 107 patients, the normalization rate for $\mathrm{GH}$ was $48 \%$ during lanreotide SR and 56\% during lanreotide Autogel ${ }^{\circledR}$ therapy, whereas a normal IGF-I was obtained in respectively $45 \%$ and $48 \%$ of cases (Caron et al 2002). In an extension phase of this study to 12 months, normalized GH frequency increased from $49 \%$ to $68 \%$ in 130 patients; these figures were $44 \%$ and $50 \%$ for IGF-I (Caron et al 2004). Fourteen patients of these studies were treated for 3 years with lanreotide Autoge ${ }^{\circledR}$. In these patients the frequency of normal GH increased from $36 \%$ to $77 \%$ and that for IGF-I from 36\% to $54 \%$ (Caron et al 2006). Finally, the Spanish multicenter study extended the Autogel ${ }^{\circledR}$ injection interval to 8 weeks in patients who were controlled by 2 -weekly injections with lanreotide SR. The overall GH control increased from $46 \%$ to $54 \%$ (Lucas et al 2006). The studies comparing the efficacy between octreotide LAR and lanreotide are shown in Table 6. Only the small study by Andries was properly designed, and showed equal efficacies of both drugs in terms of normalization of GH. Nevertheless, this study demonstrated a better GH-suppressive effect of octreotide on absolute GH concentrations than lanreotide. In contrast, the suppressive effect on IGF-I was similar. There was no difference in GH suppressive effect in a small study in 7 patients in whom the $24 \mathrm{~h} \mathrm{GH}$ secretion was precisely measured with a $10 \mathrm{~min}$ blood sampling protocol. (Van Thiel et al 2004). From the data presented above and despite limitations in design, it would appear that lanreotide Autoge ${ }^{\circledR}$ and octreotide LAR are equipotent in normalizing GH and IGF-I concentrations. Although patients require generally the highest lanreotide dose, most patients on octreotide LAR had safe GH and normal IGF-I levels on the $20 \mathrm{mg}$ dose. For the practicing endocrinologist the message is that patients on octreotide LAR 20-30 mg need $120 \mathrm{mg}$ lanreotide Autogel ${ }^{\circledR}$ and somatostatinsensitive patients on octreotide LAR $10 \mathrm{mg}$ require mostly $90 \mathrm{mg}$ of the Autogel ${ }^{\circledR}$ formulation. Lanreotide Autogel ${ }^{\circledR}$ is registered under the trade name Somatuline Autogel ${ }^{\circledR}$ in the majority of countries, as Somatuline Depot Injection ${ }^{\circledR}$ in the US, and as Ipstyl Autoge ${ }^{\circledR}$ in a few European countries.

\section{Side effects}

The most frequent side effects of lanreotide are diarrhea, abdominal pain, and nausea. These symptoms start mostly shortly after an injection, decrease subsequently, and tend to decrease in severity on continuing treatment. Table 7 lists the side effects mentioned in the clinical studies with the 2 long-acting formulations of lanreotide. For the SR formulation the gastrointestinal side effects were observed in $48 \%$ of the patients and for the Autoge $l^{\circledR}$ formulation in $52 \%$. The most serious complication of somatostatin analogs is cholelithiasis. The prevalence of somatostatin analog-induced gallstones varies geographically and may be influenced by dietary, environmental, and racial factors. The formation of gallstones involves the inhibition of gallbladder emptying and intestinal motility, inhibition of the secretion of prokinetic peptides, including cholecystokinin, and increased intestinal and biliary production of deoxycholic acid, all of which promote the nucleation of cholesterol crystals and their aggregation into stones (Dowling et al 1992). We analyzed the occurrence of new cholelithiasis in patients who were already on somatostatin analog treatment, a condition thus not quite comparable to drug-naïve patients in terms of risk of developing gallstones. The incidence of new gallstones was $6 \%$ for lanreotide SR and $8.7 \%$ for lanreotide Autogel ${ }^{\circledR}$. These figures are smaller than generally cited in literature,

Table 6 Efficacy of lanreotide Autogel ${ }^{\circledR}$ compared with octreotide LAR and lanreotide SR in acromegaly

\begin{tabular}{|c|c|c|c|c|c|c|c|c|}
\hline Reference & $\begin{array}{l}\text { Duration } \\
\text { (months) }\end{array}$ & $\begin{array}{l}\text { Patient no } \\
\text { ITT/PPP }\end{array}$ & $\begin{array}{l}\text { Octreotide } \\
\text { LAR dose }\end{array}$ & $\begin{array}{l}\text { Lanreotide } \\
\text { Autogel dose }\end{array}$ & $\begin{array}{l}\text { Normal GH } \\
\text { oLAR }\end{array}$ & $\begin{array}{l}\text { Normal GH } \\
\text { lanreotide } \\
\text { Autogel }\end{array}$ & $\begin{array}{l}\text { Normal IGF-I } \\
\text { oLAR }\end{array}$ & $\begin{array}{l}\text { Normal IGF-I } \\
\text { lanreotide } \\
\text { Autogel }\end{array}$ \\
\hline $\begin{array}{l}\text { Alexopoulou } \\
2004\end{array}$ & 6 & $25 / 25$ & $20-40 \mathrm{mg} / 4 \mathrm{w}$ & $60 / 90 / 120 \mathrm{mg}$ & $64 \%$ & $48 \%$ & $52 \%$ & $52 \%$ \\
\hline Ronchi 2007 & 9 & $23 / 21$ & $10-30 \mathrm{mg} / 4 \mathrm{w}$ & $60 / 90 / 120 \mathrm{mg}$ & $40 \%$ & $56 \%$ & $35 \%$ & $39 \%$ \\
\hline $\begin{array}{l}\text { Andries } \\
2008\end{array}$ & 12 & $12 / 10$ & $10-30 \mathrm{mg} / 4 \mathrm{w}$ & $\begin{array}{l}\text { Fixed dose } \\
60 / 90 / / 20 \mathrm{mg}\end{array}$ & $50 \%$ & $50 \%$ a & $50 \%$ & $60 \%$ \\
\hline
\end{tabular}

${ }^{a}$ normal GH concentration $<0.38 \mu \mathrm{g} / \mathrm{L}$.

Abbreviations: ITT, intention-to-treat; PPP, patients per protocol; oLAR, octreotide LAR. 
Table 7 Side effects during treatment with lanreotide SR and lanreotide Autoge ${ }^{\circledR}$ in acromegaly

\begin{tabular}{|c|c|c|c|c|c|c|c|}
\hline Author & $\begin{array}{l}\text { Number } \\
\text { of patients }\end{array}$ & $\begin{array}{l}\text { Number } \\
\text { of naive patients }\end{array}$ & $\begin{array}{l}\text { Current } \\
\text { treatment }\end{array}$ & GI side effects & $\begin{array}{l}\text { New } \\
\text { cholelithiasis }\end{array}$ & Fasting glucose & $\begin{array}{l}\text { Tumor size } \\
\text { decrease }\end{array}$ \\
\hline Heron 1993 & 14 & 0 & LSR 30 mg & 9 & 2 & $\mathrm{nc}$ & \\
\hline Morange 1994 & 19 & 0 & LSR 30 mg & 3 & 2 & $\mathrm{nc}$ & \\
\hline Johnson 1994 & 8 & 3 & LSR 30 mg & 5 & 1 & nd & nd \\
\hline Marek 1994 & 13 & 0 & LSR 30 mg & 13 & 1 & $\mathrm{nc}$ & $5 / 13(>20 \%)$ \\
\hline Giusti 1996 & 57 & 0 & LSR $30 \mathrm{mg}$ & 22 & 2 & $\mathrm{nc}$ & \\
\hline al-Maskiri 1996 & 10 & 0 & LSR 30 mg & 10 & 1 & nc & \\
\hline Caron 1997 & 22 & 0 & LSR 30 mg & 13 & 4 & $\mathrm{nc}$ & \\
\hline Suliman 1999 & 30 & 7 & LSR 30 mg & 26 & 2 & $\mathrm{nc}$ & $\mathrm{I} / 7$ \\
\hline Colao 1999 & 45 & 0 & LSR 30 mg & 12 & 1 & $\mathrm{~nm}$ & \\
\hline Chanson 2000a & 58 & 0 & LSR 30 mg & 40 & 6 & $\mathrm{nc}$ & \\
\hline Baldelli 2000 & 118 & $23^{a}$ & LSR 30 mg & 64 & 4 & $\mathrm{~nm}$. & $5 / 23(>20 \%)$ \\
\hline Cozzi 2000 & 21 & 8 & LSR 60 mg & nd & 0 & $\mathrm{nc}$ & $5 / 13$ \\
\hline Cannavo 2000 & 22 & 0 & LSR 30 mg & few & 2 & $\mathrm{~nm}$. & \\
\hline Verhelst 2000 & 66 & 3 & LSR 30 mg & 41 & 2 & $\mathrm{nc}$ & \\
\hline Ambrosio 2002 & 20 & 0 & LSR 60 mg & 10 & 0 & nc & $0 / 4$ \\
\hline Attanasio 2003b & 92 & 22 & LSR 60 mg & 8 & 10 & $\mathrm{nc}$ & $1 \mathrm{I} / 22$ \\
\hline Caron 2004 & 130 & 0 & LAUT & 58 & 12 & nd & \\
\hline Ashwell 2004 & 12 & 0 & LAUT & 0 & nd & nd & \\
\hline Alexopoulou 2004 & 25 & 0 & LAUT & 8 & 0 & $\mathrm{nc}$ & \\
\hline Ronchi 2007 & 23 & 0 & LAUT & nd & 1 & nc & \\
\hline Chanson 2008 & 63 & nd & LAUT & 53 & 8 & increase in 4 & \\
\hline
\end{tabular}

Decrease of tumor size is given only for patients who had no previous radiotherapy or somatostatin analog treatment. ${ }^{\text {aSix }}$ patients had been treated with bromocriptin. Abbreviations: nd, no data available; nc, no significant change of glucose concentrations; nm, not mentioned; LSR, lanreotide slow release; LAUT, lanreotide Autogel.

but many patients had cholelithiasis caused by previous treatment.

Other side effects were local pain after injection and rarely (less than 1\%) the development of nodules at the injection site. However, local infiltration signs did not decrease the efficacy of the drug. Other uncommon side effects included sinus bradycardia, asthenia, headache, pruritus, decreased libido, increased serum bilirubin, fatigue, constipation, and hair loss.

\section{Influence of lanreotide Autogel ${ }^{\circledR}$ on clinical manifestations}

Some studies have investigated specific aspects of lanreotide action in acromegaly. These include detailed studies on glucose and insulin metabolism, effects on cardiac function, tumor growth, quality of life, and predictors of clinical response. These reports are briefly summarized below.

\section{Insulin and glucose homeostasis}

$\mathrm{GH}$ is important in regulating glucose tolerance and insulin sensitivity. GH counteracts the effects of insulin by inhibiting the phosphorylation of the insulin receptor. Moreover, $\mathrm{GH}$ also inhibits the phosphorylation of one of the proximate molecules of the insulin signaling cascade, insulin receptor substrate-1 in response to insulin (Kuhn et al 1992). In acromegaly, several studies have shown that increased GH induces insulin resistance (Kasayama et al 2000). However, $\mathrm{GH}$ also potentiates insulin release which is reflected in the high prevalence of high insulin levels both at rest and after glucose challenge (Cerasi and Luft 1964). Indeed, many untreated patients exhibit decreased glucose tolerance and more detailed studies have shown reduced insulin-stimulated glucose disposal in muscle and impaired non-oxidative glucose metabolism (Sonksen et al 1967; Wass et al 1980; Hansen et al 1986; Foss et al 1991; Koop et al 1994). Effects of somatostatin analogs on glucose homeostasis are the resultant of delayed intestinal absorption of carbohydrates, inhibition of insulin release and increased insulin sensitivity via diminished GH secretion. Results from studies with lanreotide do not differ essentially from earlier data obtained with octreotide. The acute effects of subcutaneously infused lanreotide were studied in healthy subjects. Oral glucose tolerance worsened during the first day of administration, but was restored on day 7 while drug administration continued (Kuhn et al 1992). In a study in 27 patients the homeostasis 
model assessment (HOMA) index improved, but not the quantitative insulin check index (QUICKI) index (Ronchi et al 2003). In a cross-sectional study with 51 acromegalic patients of whom 18 were on lanreotide Autogel ${ }^{\circledR}$ the pancreatic $\beta$-cell function deteriorated but insulin resistance remained unchanged (Steffin et al 2006). The most precise study used the euglycemic hyperinsulinemic clamp. Twentyfour patients were studied at baseline and after 6 months treatment with either octreotide LAR or with lanreotide SR. Hemoglobin A1c (HbA1c) increased significantly. In patients with a normal glucose tolerance at baseline the glucose concentration at $120 \mathrm{~min}$ increased, together with decreased and delayed insulin response. Insulin sensitivity increased in all 12 clamped patients. The investigators could not demonstrate differences between octreotide and lanreotide, ie, the effects on GH, IGF-I, and insulin were all similar (Baldelli et al 2003). The effects of other pharmacologic therapies currently used for the treatment of acromegaly on glucose metabolism and insulin resistance were recently reviewed (Pereira et al 2005). In most studies, not specifically focused on insulin and glucose metabolism, fasting glucose concentrations and/or HbA1c levels did not change significantly when the GHsuppressive medication was changed to lanreotide or when the period of lanreotide administration was compared with the period without GH-suppressive medication.

\section{Cardiac effects}

Acromegaly is associated with increased cardiac morbidity and mortality. Recognized cardiac manifestations include chronic cardiac failure due to systolic dysfunction (cardiomyopathy) or isolated diastolic dysfunction (Colao et al 2004; Pereira et al 2004). In addition, our group documented the increased prevalence of regurgitant valvular heart disease in acromegaly (Pereira et al 2004). An important question is whether effective GH-suppressive medication can improve cardiac function. One of the first studies reported on 13 patients treated with lanreotide. In this study there was a parallel decrease in GH and IGF-I and in left ventricular mass index; these data were confirmed in another study (Baldelli et al 1999; Hradec et al 1999). Octreotide was used in most studies on cardiac function, because this drug was the earliest available for clinical studies (Maison et al 2007). These studies indicate that effective GH-suppressive medication improves morphological and functional hemodynamic parameters, although medical therapy does not normalize all parameters. These observations concur with results of another study, which compared outcome in long-term surgically cured patients with medically controlled patients and which showed better results in the first group (van Thiel et al 2005), suggesting that GH-suppressive therapy in its present form is unable to fully correct cardiac dysfunction. The impact of this finding on long-term mortality in acromegaly is unknown.

\section{Tumor growth}

The anti-tumoral effects of somatostatin analogs are linked to the activation of the subtype receptors SSTR1, SSRT2, SSTR4, and SSTR5, which all induce cell cycle arrest. Apoptosis is associated with SSTR3 and possibly also with SSTR2 signaling (Danilla et al 2001; Bevan 2005). GH secreting adenomas express different somatostatin receptors, as shown for example by a recent study in which $77 \%$ expressed SSTR2, $69 \%$ SSTR 1 and SSTR3, and 60\% SSTR5. In the same study, lanreotide inhibited cell proliferation in vitro in 10 out of 13 adenomas (Florio et al 2003). Lanreotide also stimulates apoptosis as was found in surgically removed GH secreting adenomas to $8.7 \pm 2.6 \%$ in tumors compared with less than $3.5 \%$ in controls (Wasko et al 2003). The clinical response in terms of GH control and tumor size reduction correlates with the expression of somatostatin receptor subtype $2 \mathrm{a}$ (Fougner et al 2008; Taboada et al 2008) Preoperative treatment with lanreotide SR for 1-3 months in 104 acromegalic patients led to tumor size reduction in $66 \%$, with a mean decrease of $152 \mathrm{~mm}^{3}$. A decrease in adenoma size of more than $20 \%$ was found in 29\% of the patients (Lucas et al 2003). Other studies in which the decrease in adenoma size could be evaluated are listed in Table 7 . In the meta-analysis of 14 clinical studies using somatostatin analogs as primary treatment, $36.6 \%$ of the patients exhibited a significant reduction in tumor size, with a weighted mean of 19.4\% (Melmed et al 2005). Factors (not necessarily predictors) associated with tumor shrinkage after primary therapy with somatostatin analogs were posttreatment IGF-I, the age of the patient and the percentage GH decrease (Colao et al 2006a), and essentially confirming previously reported findings (Lucas et al 2003). In another meta-analysis of 44 trials, tumor shrinkage was related to the choice of the somatostatin analog. Octreotide LAR appeared to be more potent than lanreotide SR, with an odds ratio of 9.4 (Freda et al 2005). Preliminary data on biochemical remission of acromegaly after somatostatin analogs withdrawal suggest that some well-responsive patients might be cured, but longterm follow up is clearly needed (Ronchi et al 2008).

\section{Quality of life}

QoL remains impaired in acromegaly even after successful pituitary surgery due to persisting joint-related complaints 
(Biermasz et al 2005a). An early open study on the effect of lanreotide SR on QoL suggested a positive effect of treatment (Sonino et al 1999). However, in another study comprising 52 acromegalic patients no differences could be shown between lanreotide-controlled and noncontrolled patients using the AcroQoL, a questionnaire specifically developed for acromegaly. Interestingly, in the controlled group, surgically cured patients were much better off than patients controlled with lanreotide (Hua et al 2006). This observation underscores subtle differences between restoration of normal physiology and effective GH-suppressive medication, as found in intensive GH sampling studies in acromegalic cohorts (Biermasz et al 2004c). Finally, in a study of 93 patients with acromegaly control of GH and IGF-I had a positive impact on the subscale appearance, but overall QoL was severely impaired (Matta et al 2008).

\section{Predictors of clinical response}

A priori conditions for a favorable clinical response to somatostatin analog therapy are the density and distribution of SSTR2a receptors in the adenoma (Lamberts et al 1996). It is controversial whether a single acute octreotide test can predict the clinical response during long-term treatment. In this respect 3 studies reported positive results (Biermasz et al 2005b; Gilbert et al 2005; Karavitaki et al 2005), whereas 3 others concluded that the test was not useful (Colao et al 1996; de Herder et al 2005; Prokajac et al 2005). The absolute height of pretreatment GH levels is obviously another important factor for the efficacy of treatment, and indeed several studies have demonstrated that tumor debulking procedures improved the clinical outcome of medical therapy (Colao et al 2006b; Karavitaki et al 2007).

\section{Primary pharmacologic treatment}

Patients with a high chance of curative surgery should be offered this treatment. However, primary medical treatment should be considered in patients with a high surgical risk, patients with large invasive tumors and obviously in those who refuse surgery. Dose escalation with short-acting octreotide resulted in a better outcome in patients treated with octreotide as primary medication than those who received this drug as adjuvant medication after surgery (Newman et al 1995). Given as primary treatment, octreotide LAR controlled GH secretion in 57\%, IGF-I in 45\%, and caused tumor reduction of more than $50 \%$ in $44 \%$ out of 99 patients (Colao et al 2006a). This group and Cozzi and colleagues also found that dose escalating resulted in an even better outcome (Cozzi et al 2003; Colao et al 2007). Limitations of these studies are that they are not randomized to primary surgery and that no data are available on long-term effects on survival.

Primary medical treatment may also be aimed at improvement of surgical outcome. Most of the studies addressing this issue had an open label design. Three studies reported beneficial effect on outcome (Barkan et al 1988; Colao et al 1997; Stevenaert and Beckers 1996), whereas three others did not (Biermasz et al 1999; Kristof et al 1999; Abe and Lüdecke 2001). Therefore, a conclusive statement cannot be made on this issue.

\section{Failures of medical therapy}

As outlined above, somatostatin analog treatment will not control clinical symptoms and biochemical parameters in all acromegalic patients, and about half of them will still have raised IGF-I and/or GH levels. An increase in the injection frequency of lanreotide Autogel ${ }^{\circledR}$ to once every 2-3 weeks is generally not successful (Abrams et al 2007). Another, less expensive approach is to combine treatment with dopaminergic agonists (Freda 2003; Cozzi et al 2004). More effective is combined treatment with pegvisomant as demonstrated by a single center open labeled study. Long-term efficacy of combined treatment was demonstrated in 32 patients who all normalized IGF-I with pegvisomant in a dose of 40-160 mg given once weekly (24 patients) or twice weekly (Neggers et al 2007). Two large multicenter studies are respectively ongoing and complete, in which weekly administered pegvisomant is combined with lanreotide Autogel ${ }^{\circledR}$ in patients not controlled during treatment with $120 \mathrm{mg}$ lanreotide Autogel $^{\circledR}$ (ClinicalTrials.gov, NCT 00383708) and daily pegvisomant injections with ocreotide LAR (ClinicalTrials. gov, NCT 0068029). Preliminary results of the latter study suggest equal efficacy in the two randomized parallel treatment groups towards serum IGF-I normalization, but with a higher incidence of side effects in the combined treatment group (Harris et al 2007). Considering the number of patients included, these studies will most likely answer questions about the efficacy of combined somatostatin analog and GHreceptor blockage in the treatment of acromegaly. However, both studies did not exclude previous surgery or radiation therapy, so that any conclusions drawn from these studies may not be applicable to primary medical treatment.

Due the favorable receptor binding profile, SOM230 (pasireotide) is likely to be a powerful somatostatin ana$\log$, which might be used in therapy-resistant cases to the registered somatostatin analogs (van der Hoek et al 2005; Ben-Shlomo and Melmed 2007). Clinical Phase II studies 
in acromegaly are now being carried out in the US with both the short-acting form as well as the slow-release formulation (ClinTrial.gov NCT000088582, NCT00171730, and NCT00600886). Other somatostatin agonists currently developed were recently reviewed (Roelfsema et al 2006). Potential interesting drugs are chimeric somatostatin analogs. This class of drugs combines dopamine and somatostatin structural elements and retains affinity for specific somatostatin and dopamine receptor subtypes. These new drugs can not only suppress GH (and other pituitary hormones) better than currently clinically used drugs, but may also have much stronger antiproliferative actions, at least in vitro (Ferone et al 2007; Zatelli et al 2007).

\section{Summary and future perspectives}

Lanreotide Autogel ${ }^{\circledR}$ is an exceptional pharmaceutical achievement, based on the unique property of selfaggregation of lanreotide. The formulation is delivered in prefilled syringes and can be easily injected without medical supervision by the patient or partner after proper training (Bevan et al 2008), whereas octreotide LAR requires qualified personnel for administration.

Lanreotide SR $30 \mathrm{mg} / 7-14$ days can control serum $\mathrm{GH}$ in $59 \%$ and IGF-I concentrations in $49 \%$ of patients, while the results of the $60 \mathrm{mg}$ formulation/4 weeks are $60 \%$ and $58 \%$, respectively. Lanreotide Autoge ${ }^{\circledR}$ controls GH in 58\% and IGF-I in $48 \%$ of patients. Compared with octreotide LAR the efficacy of lanreotide SR is less, although the differences are not large (Freda et al 2005). No large scale data are available for lanreotide Autogel ${ }^{\circledR}$, a latecomer in this therapeutic field, for making a reasonable comparison with octreotide LAR.

The present formulations of somatostatin analogs can be classified as a second generation of effective GHsuppressive drugs, but these agents are clearly not adequate for all patients, depending on tumor somatostatin receptor status. New somatostatin analogs include SOM230, which is currently being used in several trials in the US, and the potentially very powerful chimeric drugs developed by Ipsen SA. The latter drugs, if successful in phase II-IV studies, will probably take another 5-10 years before becoming available for clinical use by endocrinologists. At present patients not controlled by somatostatin analogs should be treated with adjuvant pegvisomant, either as daily injections, as recommended by Pfizer, or as once-weekly or 2-weekly injections in a titrated dose, which data in the literature have suggested as sufficient (Feenstra et al 2005; Jørgensen et al 2005; Harris et al 2007; Neggers et al 2007). It is to be expected that other $\mathrm{GH}$ receptor blocking agents will become available in the future, which might not have the potential drawbacks of pegvisomant (Roelfsema et al 2006).

\section{Disclosures}

The authors have no conflict of interest and have received no payment in the preparation of this manuscript.

\section{References}

Abe T, Lüdecke DK. 2001. Effects of preoperative octreotide treatment on different subtypes of $90 \mathrm{GH}$-secreting pituitary adenomas and outcome in one surgical centre. Eur J Endocrinol, 145:137-45.

Abrams P, Alexopoulou O, Abs R, et al. 2007. Optimalization and cost management of lanreotide-Autogel therapy in acromegaly. Eur $J$ Endocrinol, 157:571-7.

Abs R, Verhelst J, Maiter D, et al. 1998. Cabergoline in the treatment of acromegaly: a study in 64 patients. $J$ Clin Endocrinol Metab, 83:374-8.

Ahmed S, Elsheikh M, Stratton IM, et al. 1999. Outcome of transsphenoidal surgery for acromegaly and its relationship to surgical experience. Clin Endocrinol (Oxf), 50:561-7.

Alexander L, Appleton D, Hall R, et al.1980. Epidemiology of acromegaly in the Newcastle region. Clin Endocrinol (Oxf), 12:71-9.

Alexopoulou O, Abrams P, Verhelst J, et al. 2004. Efficacy and tolerability of lanreotide Autogel therapy in acromegalic patients previously treated with octreotide LAR. Eur J Endocrinol, 151:317-24.

al-Maskari M, Gebbie J, Kendall-Taylor P. 1996. The effect of a new slowrelease, long-acting somatostatin analogue, lanreotide, in acromegaly. Clin Endocrinol (Oxf), 45:415-21.

Amato G, Mazziotti G, Rotondi M, et al. 2002. Long-term effects of lanreotide SR and octreotide LAR on tumour shrinkage and GH hypersecretion in patients with previously untreated acromegaly. Clin Endocrinol (Oxf), 56:65-71.

Ambrosio MR, Franceschetti P, Bondanelli M, et al. 2002. Efficacy and safety of the new $60-\mathrm{mg}$ formulation of the long-acting somatostatin analog lanreotide in the treatment of acromegaly. Metabolism, 51:387-93.

Andries M, Glintborg D, Kvistborg A, et al. 2008. A 12-month randomized crossover study on the effects of lanreotide Autogel and octreotide long-acting repeatable on GH and IGF-1 in patients with acromegaly. Clin Endocrinol (Oxf), 68:473-80.

Antonijoan RM, Barbanoj MJ, Cordero JA, et al. 2004. Pharmacokinetics of a new Autogel formulation of the somatostatin analogue lanreotide after a single subcutaneous dose in healthy volunteers. J Pharm Pharmacol, 56:471-6.

Ashwell SG, Bevan JS, Edwards OM, et al. 2004. The efficacy and safety of lanreotide Autogel in patients with acromegaly previously treated with octreotide LAR. Eur J Endocrinol, 150:473-80.

Astruc B, Marbach P, Bouterfa H, et al. 2005. Long-acting octreotide and prolonged-release lanreotide formulations have different pharmacokinetic profiles. J Clin Pharmacol, 45:836-44.

Attanasio R, Baldelli R, Pivonello R, et al. 2003b. Lanreotide $60 \mathrm{mg}$, a new long-acting formulation: effectiveness in the chronic treatment of acromegaly. J Clin Endocrinol Metab, 88:5258-65.

Attanasio R, Epaminonda P, Motti E, et al. 2003a. Gamma-knife radiosurgery in acromegaly: A 4-year follow-up study. J Clin Endocrinol Metab, 88:3105-12

Ayuk J, Clayton RN, Holder G et al. 2004. Growth hormone and pituitary radiotherapy, but not serum insulin-like growth factor I concentrations predict excess mortality in patients with acromegaly. J Clin Endocrinol Metab, 89:1613-17.

Baldelli R, Battista C, Leonetti F, et al. 2003. Glucose homeostasis in acromegaly: effects of long-acting somatostatin analogues treatment. Clin Endocrinol (Oxf), 59:492-9.

Baldelli R, Colao A, Razzore P, et al. 2000. Two-year follow-up of acromegalic patients treated with slow release lanreotide $(30 \mathrm{mg}) . J$ Clin Endocrinol Metab, 85:4099-103. 
Baldelli R, Ferretti E, Jaffrain-Rea ML, et al. 1999. Cardiac effects of slow-release lanreotide, a slow-release somatostatin analog, in acromegalic patients. J Clin Endocrinol Metab, 84:527-32.

Barkan AL, Halasz I, Dornfeld KJ, et al. 1997. Pituitary irradiation is ineffective in normalizing plasma insulin-like growth factor I in patients with acromegaly. J Clin Endocrinol Metab, 82:3187-91.

Barkan AL, Lloyd RV, Chandler WF, et al. 1988. Preoperative treatment of acromegaly with long-acting somatostatin analog SMS 201-995: shrinkage of invasive pituitary macroadenomas and improved surgical remission rate. J Clin Endocrinol Metab, 76:1040-8.

Barkan AL, Stred SE, Reno K, et al. 1989. Increased growth hormone pulse frequency in acromegaly. J Clin Endocrinol Metab, 69:1225-33.

Barrande G, Pittino-Lungo M, Coste J, et al. 2000. Hormonal and metabolic effects of radiotherapy in acromegaly: long-term results in 128 patients followed in a single center. J Clin Endocrinol Metab, 85:3779-85.

Bates AS, Van'tHoff W, Jones JM, et al. 1993. An audit of outcome of treatment in acromegaly. Q J Med, 86:293-9.

Bates PR, Carson MN, Trainer PJ, et al. 2008. Wide variation in surgical outcomes for acromegaly in the UK. Clin Endocrinol (Oxf), 68:136-42.

Beauregard C, Truong U, Hardy J, Serri O, 2003. Long-term outcome and mortality after transsphenoidal adenomectomy for acromegaly. Clin Endocrinol (Oxf), 58:86-91.

Bengtsson BA, Eden S, Ernest I, et al. 1988. Epidemiology and long-term survival in acromegaly. A study of 166 cases diagnosed between 1955 and 1984. Acta Med. Scand, 223:327-35.

Ben-Shlomo A, Melmed S. 2007. Pasireotide - a somatostatin analog for the potential treatment of acromegaly, neuroendocrine tumors and Cushing's disease. Drugs, 10:885-95.

Ben-Shlomo A, Melmed S. 2008. Acromegaly. Endocrinol Metab N Am, 27:101-22.

Bevan JS. 2005. Clinical review: The antitumoral effects of somatostatin analog therapy in acromegaly $J$ Clin Endocrinol Metab, 90:1856-63.

Bevan JS, Newell-Price J, Wass JAH, et al. 2008. Home administration of lanreotide Autogel by patients with acromegaly, or their partners, is safe and effective. Clin Endocrinol (Oxford), 68: 343-349.

Bidlingmaier M, Strasburger CJ. 2007. Growth hormone assays: current methodologies and their limitations. Pituitary, 10:115-19.

Biermasz NR, Dekker FW, Pereira AM, et al. 2004a. Determinants of survival in treated acromegaly in a single center: predictive value of serial insulin-like growth factor-I measurements. $J$ Clin Endocrinol Metab, 89:2789-96.

Biermasz NR, Pereira AM, Frolich M, et al. 2004c. Octreotide represses secretory-burst mass and non-pulsatile secretion but does not restore event frequency of orderly GH secretion in acromegaly. Am J Physiol Endocrinol Metab, 286:E25-E30.

Biermasz NR, Pereira AM, Neelis KJ, et al. 2006. The role of radiotherapy in the management of acromegaly. Expert Rev Endocrinol Metab, 1:449-60.

Biermasz NR, Pereira AM, Smit JW, et al. 2005a. Morbidity after long-term remission for acromegaly: persisting joint-related complaints cause reduced quality of life. J Clin Endocrinol Metab, 90:2731-9.

Biermasz NR, Pereira AM, Smit JW, et al. 2005b. Intravenous octreotide test predicts the long term outcome of treatment with octreotide-long-acting repeatable in active acromegaly. Growth Horm IGF Res, 15:200-6.

Biermasz NR, Smit JW, Pereira AM, et al. 2007. Acromegaly caused by growth hormone-releasing hormone-producing tumors: long-term observational studies in three patients. Pituitary, 10:237-49.

Biermasz NR, van Dulken H, Roelfsema F. 1999. Direct postoperative and follow-up results of transsphenoidal surgery in 19 acromegalic patients pretreated with octreotide compared to those in untreated matched controls. J Clin Endocrinol Metab, 84:3551-5.

Biermasz NR, van Dulken H, Roelfsema F. 2000a. Ten-year follow-up results of transsphenoidal microsurgery in acromegaly. J Clin Endocrinol Metab, 85:4596-602.

Biermasz NR, van Dulken H, Roelfsema F. 2000b. Postoperative radiotherapy in acromegaly is effective in reducing GH concentration to safe levels. Clin Endocrinol (Oxf), 53:321-7.
Biermasz NR, van Thiel SW, Pereira AM, et al. 2004b. Decreased quality of life in patients with acromegaly despite long-term cure of growth hormone excess. J Clin Endocrinol Metab, 89:5369-76.

Brada M, Ajithkumar TV, Minniti G, et al. 2004. Radiosurgery for pituitary adenomas. Clin Endocrinol (Oxf), 61:531-43.

Brada M, Ford D, Ashley S, et al. 1992. Risk of second brain tumour after conservative surgery and radiotherapy for pituitary adenoma. $B M J$, 304:1343-6.

Brazeau P, Vale W, Burgus R, et al.1973. Hypothalamic polypeptide that inhibits the secretion of immunoreactive pituitary growth hormone. Science, 179:77-9.

Bronstein M, Musolino N, Jallad R, et al. 2005. Pharmacokinetic profile of lanreotide Autogel in patients with acromegaly after four deep subcutaneous injections of 60,90 or $120 \mathrm{mg}$ every 28 days. Clin Endocrinol (Oxf), 63:514-19.

Cannavo S, Squadrito S, Curto L, et al. 2000. Results of a two-year treatment with slow release lanreotide in acromegaly. Horm Metab Res, 32:224-9.

Caron P, Beckers A, Cullen DR, et al. 2002. Efficacy of the new long-acting formulation of lanreotide (lanreotide Autogel) in the management of acromegaly. J Clin Endocrinol Metab, 87:99-104.

Caron P, Bex M, Cullen DR, et al. 2004. One-year follow-up of patients with acromegaly treated with fixed or titrated doses of lanreotide Autogel. Clin Endocrinol (Oxf), 60:734-40.

Caron P, Cogne M, Raingeard I, et al. 2006. Effectiveness and tolerability of 3-year lanreotide Autogel treatment in patients with acromegaly. Clin Endocrinol (Oxf), 64:209-14.

Caron P, Morange-Ramos I, Cogne M, et al. 1997. Three year follow-up of acromegalic patients treated with intramuscular slow-release lanreotide. $J$ Clin Endocrinol Metab, 82:18-22.

Castinetti F, Taieb D, Kuhn JM, et al. 2005. Outcome of gamma knife radiosurgery in 82 patients with acromegaly: correlation with initial hypersecretion. J Clin Endocrinol Metab, 90:4483-8.

Cerasi E, Luft R. 1964. Insulin response to glucose loading in acromegaly. Lancet, 284:769-71.

Chanson P, Boerlin V, Ajzenberg C, et al. 2000b. Comparison of octreotide acetate LAR and lanreotide SR in patients with acromegaly. Clin Endocrinol (Oxf), 53:577-86.

Chanson P, Borson-Chazot F, Kuhn JM, et al. 2008. Control of IGF-I levels with titrated dosing of lanreotide Autogel over 48 weeks in patients with acromegaly. Clin Endocrinol (Oxf), doi: 10.1111/j.13652265.2008.03208.x

Chanson P, Leselbaum A, Blumberg J, et al. 2000a. Efficacy and tolerability of the long-acting somatostatin analog lanreotide in acromegaly. A 12-month multicenter study of 58 acromegalic patients. French Multicenter Study Group on Lanreotide in Acromegaly. Pituitary, 2:269-76.

Ciccarelli E, Valetto MR, Vassario E, et al. 1993. Hormonal and radiological effects of megavoltage radiotherapy in patients with growth hormonesecreting pituitary adenoma. J Endocrinol Invest, 16:565-72.

Clayton RN. 2003. Cardiovascular function in acromegaly. Endocr Rev, 24:272-7.

Clemmons DR. 2007. IGF-I assays: current assay methodologies and their limitations. Pituitary, 10:121-8.

Colao A, Attanasio R, Pivonello R, et al. 2006b. Partial surgical removal of growth hormone-secreting pituitary tumors enhances the response to somatostatin analogs in acromegaly.J Clin Endocrinol Metab, 91:85-92.

Colao A, Ferone D, Cappabianca, et al. 1997. Effect of octreotide pretreatment on surgical outcome in acromegaly. J Clin Endocrinol Metab, 82:3308-14.

Colao A, Ferone D, Lastoria S, et al. 1996. Prediction of efficacy of octreotide therapy in patients with acromegaly. J Clin Endocrinol Metab, 81:2356-62.

Colao A, Ferone D, Marzullo P, et al. 2004. Systemic complications of acromegaly: epidemiology, pathogenesis, and management. Endocr Rev, 25:102-52. 
Colao A, Marzullo P, Ferone D, et al. 1999. Effectiveness and tolerability of slow release lanreotide treatment in active acromegaly. J Endocrinol Invest, 22:40-7.

Colao A, Pivonello R, Auriemma RS, et al. 2006a. Predictors of tumor shrinkage after primary therapy with somatostatin analogs in acromegaly : a prospective study in 99 patients. $J$ Clin Endocrinol Metab, 91:2112-18.

Colao A, Pivonello R, Aurriemma RS, et al. 2007. Beneficial effect of dose escalation of octreotide-LAR as first-line therapy in patients with acromegaly. Eur J Endocrinol, 157:579-87.

Cozzi R, Attanasio R, Montini M, et al. 2003. Four-year treatment with octreotide-LAR in 110 acromegalic patients: the predictive value of short-term results by ROC analysis. J Clin Endocrinol Metab, 88:3090-8.

Cozzi R, Attanasio R, Lodrini S, et al. 2004. Cabergoline addition to depot somatostatin analogues in resistant acromegalic patients: efficacy and lack of predictive value of prolactin status. Clin Endocrinol (Oxf), 61:209-15.

Cozzi R, Barausse M, Ashnaghi D, et al. 2001. Failure of radiotherapy in acromegaly. Eur J Endocrinol, 145:717-26.

Cozzi R, Barausse M, Sberna M, et al. 2000. Lanreotide $60 \mathrm{mg}$, a longeracting somatostatin analog: tumor shrinkage and hormonal normalization in acromegaly. Pituitary, 3:231-8.

Cozzi R, Dallabonzana D, Attanasio R, et al. 1999. A comparison between octreotide-LAR and lanreotide-SR in the chronic treatment of acromegaly. Eur J Endocrinol, 141:267-71.

Danila DC, Haidar JN, Zhang X, et al. 2001. Somatostatin receptor-specific analogs: effects on cell proliferation and growth hormone secretion in human somatotroph tumors. J Clin Endocrinol Metab, 86: 2976-81.

De P, Rees DA, Davies N, et al. 2003. Transsphenoidal surgery for acromegaly in Wales: results based on stringent criteria of remission. $J$ Clin Endocrinol Metab, 88:3567-72.

De Herder WW, Taal HR, Uitterlinden P, et al. 2005. Limited predictive value of an acute test with subcutaneous octreotide for long-term IGF-I normalization with Sandostatin-LAR in acromegaly. Eur J Endocrinol, 153:67-71.

Dekkers OM, Biermasz NR, Pereira AM, et al. 2008. Mortality in acromegaly: a meta-analysis. J Clin Endocrinol Metab, 93: 61-7.

Dowling RH, Hussaini SH, Murphy GM, Besser GM, Wass JAH. 1992. Gallstones during octreotide therapy. Metabolism, 41(Suppl 2):22-33.

Epaminonda R, Porretti S, Cappiello V, et al. 2001. Efficacy of radiotherapy in normalizing serum IGF-I, acid labile subunit (ALS) and IGFBP-3 levels in acromegaly. Clin Endocrinol (Oxf), 55: 183-9.

Ezzat S, Forster MJ, Berchtold P, et al. 1994. Acromegaly. Clinical and biochemical features in 500 patients. Medicine (Baltimore), 73:233-40.

Fahlbusch R, Keller B, Ganslandt O, et al. 2005. Transsphenoidal surgery in acromegaly investigated by intraoperative high-field magnetic resonance imaging. Eur J Endocrinol, 153:239-48.

Feenstra J, de Herder WW, ten Have SMTH, et al. 2005. Combined therapy with somatostatin analogues and weekly pegvisomant in active acromegaly. Lancet, 365:63011-15.

Ferone D, Saveanu A, Culler MD, et al. 2007. Novel chimeric somatostatin analogs: facts and perspectives. Eur J Endocrinol, 156:S23-S8.

Florio T, Thellung S, Corsaro A, et al. 2003. Characterization of the intracellular mechanisms mediating somatostatin and lanreotide inhibition of DNA synthesis and growth hormone release from dispersed human GH-secreting pituitary adenoma cells in vitro. Clin Endocrinol (Oxf), 59:115-28.

Foss MC, Saad MJ, Paccola GM, et al. 1991. Peripheral glucose metabolism in acromegaly. J Clin Endocrinol Metab, 72:1048-53.

Fougner SL, Borota OC, Berg JP, et al. 2008. The clinical response to somatostatin analogues in acromegaly correlates to the somatostatin receptor subtype 2a protein expression of the adenoma. Clin Endocrinol (Oxf), 68:458-65.

Freda PU. 2003. How effective are current therapies for acromegaly? Growth Horm IGF Res, 13(Suppl A):S144-S51.
Freda PU, Katznelson L, van der Lely AJ, et al. 2005. Long-acting somatostatin analog therapy of acromegaly: a meta-analysis. $J$ Clin Endocrinol Metab, 90:4465-73.

Freda PU, Wardlaw SL, Post KD, et al. 1998. Long-term endocrinological follow-up evaluation in 115 patients who underwent transsphenoidal surgery for acromegaly. $J$ Neurosurg, 89:353-8.

Gilbert JA, Miell JP, Chambers, et al. 2005. The nadir growth hormone after an octreotide test dose predicts the long-term efficacy of somatostatin analogue therapy in acromegaly. Clin Endocrinol (Oxf), 620:742-7.

Giusti M, Ciccarelli E, Dallabonzana D, et al. 1997. Clinical results of long-term slow-release lanreotide treatment of acromegaly. Eur J Clin Invest, 27:277-84.

Giustina A, Barkan A, Casanueva FF, et al. 2000. Consensus. Criteria for cure of acromegaly: a consensus statement. J Clin Endocrinol Metab, 85:526-9.

Greenman Y, Tordjman K, Kisch E, et al. 1995. Relative sparing of anterior pituitary function in patients with growth hormonesecreting macroadenomas: comparison with nonfunctioning macroadenomas. J Clin Endocrinol Metab, 80:1577-83.

Gullu S, Keles H, Delibasi T, et al. 2004. Remission criteria for the follow-up of patients with acromegaly. Eur J Endocrinol, 150:465-71.

Gutt B, Bidlingmaier M, Kretschmar K, et al. 2005. Four-year follow-up of acromegalic patients treated with the new long-acting formulation of Lanreotide (Lanreotide Autogel). Exp Clin Endocrinol Diabetes, 113:139-44.

Hansen I, Isalikian E, Beaufrere B, et al. 1986. Insulin resistance in acromegaly: defects in both hepatic and extrahepatic insulin action. Am J Physiol, 250: E269-E73.

Harris PE, D'Souza G, Good AJ, et al. 2007. Treatm ent with pegvisomant alone compared to combination therapy with pegvisomant/octreotide LAR in acromegaly. Abstract OR 53-3.The Endocrine Society Annual Meeting, Toronto, Ontario, Canada, June 2-5, 2007.

Heron I, Thomas F, Dero M, et al. 1993. Pharmacokinetics and efficacy of a long-acting formulation of the new somatostatin analog BIM 23014 in patients with acromegaly. J Clin Endocrinol Metab, 76:721-7.

Ho KY, Weisberger AJ. 1994. Characterization of 24-hour growth hormone secretion in acromegaly: implications for diagnosis and therapy. Clin Endocrinol (Oxf), 41:75-83.

Hofland LJ, Lamberts SWJ. 2003. The Pathophysiological Consequences of Somatostatin Receptor Internalization and Resistance. Endocr Rev, 24:28-47.

Holdaway IM. 2007. Excess mortality in acromegaly. Horm Res, (Suppl 5):166-72.

Holdaway IM, Rajasoorya RC, Gamble GD. 2004. Factors influencing mortality in acromegaly. J Clin Endocrinol Metab, 89:667-74.

Hradec J, Krai J, Janota T, et al. 1999. Regression of acromegalic left ventricular hypertrophy after lanreotide (a slow-release somatostatin analog). Am J Cardiol, 83:1506-9.

Hua SC, Yan YH, Chang TC. 2006. Associations of remission status and lanreotide treatment with quality of life in patients with treated acromegaly. Eur J Endocrinol, 155:831-7.

Jaffe CA, Barkan AL. 1992. Treatment of acromegaly with dopamine agonists. Endocrinol Metab Clin North Am, 21:713-35.

Jenkins PJ, Besser M. 2001. Clinical perspective: acromegaly and cancer: a problem. J Clin Endocrinol Metab, 86:2935-41.

Johnson MR, Chowdrey HS, Thomas F, et al. 1994. Pharmacokinetics and efficacy of the long-acting somatostatin analogue somatuline in acromegaly. Eur J Endocrinol, 130:229-34.

Jørgensen JOL, Feldt-Rasmusen U, Frystyk J, et al. 2005. Cotreatment of acromegaly with a somatostatin analog and a growth hormone receptor antagonist. J Clin Endocrinol Metab, 90:5627-31.

Kaltsas GA, Isidori AM, Florakis D, et al. 2001. Predictors of outcome of surgical treatment in acromegaly and the value of the mean growth hormone day curve in assessing postoperative disease activity. $J$ Clin Endocrinol Metab, 86:1645-52. 
Karavitaki N, Botusan I, Radian S, et al. 2005. The value of an acute octreotide suppression test in predicting long-term responses to depot somatostatin analogues in patients with active acromegaly. Clin Endocrinol (Oxf), 62:282-8.

Karavitaki N, Turner HE, Adams CB, et al. 2007. Surgical debulking of pituitary macroadenomas causing acromegaly improves control by lanreotide. Clin Endocrinol (Oxf), doi: 10.1111/j.1365-2265.2007.03139.x.

Kasayama S, Otsuki M, Tagaki M, et al. 2000. Impaired beta-cell function in the presence of reduced insulin sensitivity determines glucose tolerance status in acromegalic patients. Clin Endocrinol (Oxf), 52:549-55.

Kauppinen-Makelin R, Sane T, Reunanen A, et al. 2005. A nationwide survey of mortality in acromegaly. J Clin Endocrinol Metab, 90:4081-6.

Kendall-Taylor P, Miller M, Gebbie J, et al. 2000. Long-acting octreotide LAR compared with lanreotide SR in the treatment of acromegaly. Pituitary, 3:61-5.

Krantic S, Goddard I, Saveanu A, et al. 2004. Novel modalities of somatostatin actions. Eur J Endocrinol, 151:643-55.

Kreutzer J, Vance ML, Lopes MB, et al. 2001. Surgical management of GH-secreting pituitary adenomas: an outcome study using modern remission criteria. J Clin Endocrinol Metab, 86:4072-7.

Koop BL, Harris AG, Ezzat S. 1994. Effect of octreotide on glucose tolerance in acromegaly. Eur J Endocrinol, 130:581-6.

Kristof RA, Stoffel-Wagner B, Klingmuller D, et al. 1999. Does octreotide treatment improve the surgical results of macroadenomas in acromegaly? A randomized study. Acta Neurochirg, 141:399-405.

Kuhn JM, Basin C, Mollard M, et al. 1992. Effects of the new somatostatin analogue (BIM 23014) on blood glucose homeostasis in normal men. Eur J Clin Invest, 22:793-9.

Kuhn JM, Legrand A, Ruiz JM, et al. 1994. Pharmacokinetic and pharmacodynamic properties of a long-acting formulation of the new somatostatin analogue, lanreotide, in normal healthy volunteers. $\mathrm{Br} J$ Clin Pharmacol, 38:213-19.

Lamberts SW, Van der Lely AJ, De Herder WW, et al. 1996. Octreotide. N Engl J Med, 334:246-54.

Landolt AM, Haller D, Lomax N, et al. 1998. Stereotactic radiosurgery for recurrent surgically treated acromegaly: comparison with fractionated radiotherapy. J Neurosurg, 88:1002-8.

Le Roith D, Bondy C, Yakar S, et al. 2001. The somatomedin hypothesis. Endocr Rev, 22:53-74.

Loeper S, Ezzat S. 2008. Acromegaly: Re-thinking the cancer risk. Rev Endocr Metab Disord, 9:41-58.

Long H, Beauregard H, Somma M, et al. 1996. Surgical outcome after repeated transsphenoidal surgery in acromegaly. $J$ Neurosurg, 85:239-47.

Lucas T, Astorga R, Catala M, et al. 2003. Preoperative lanreotide treatment for GH-secreting pituitary adenomas: effect on tumour volume and predictive factors of significant tumour shrinkage. Clin Endocrinol $(O x f), 58: 471-81$.

Lucas T, Astorga R; Spanish-Portuguese Multicentre Autogel Study Group on Acromegaly. 2006. Efficacy of lanreotide Autogel administered every 4-8 weeks in patients with acromegaly previously responsive to lanreotide microparticles $30 \mathrm{mg}$ : a phase III trial. Clin Endocrinol (Oxf), 65:320-6.

Lüdecke DK, Abe T. 2006. Transsphenoidal microsurgery for newly diagnosed acromegaly: a personal view after more than 1000 operations. Neuroendocrinology, 83:230-9.

Mahmoud-Ahmed AS, Suh JH, Mayberg MR. 2001. Gamma knife radiosurgery in the management of patients with acromegaly: a review. Pituitary, 4:223-30.

Maison P, Tropeano A-I, Macquin-Mavier I, et al. 2007. Impact of somatostatin analogs on the heart in acromegaly: a metaanalysis. $J$ Clin Endocrinol Metab, 92:1743-7.

Marcou Y, Plowman PN. 2000. Stereotactic radiosurgery for pituitary adenomas. Trends Endocrinol Metab, 11: 132-7.

Marek J, Hana V, Krsek M, et al. 1994. Long-term treatment of acromegaly with the slow-release somatostatin analogue lanreotide. Eur J Endocrinol, 131:20-26.
Matta MP, Couture E, Cazals L, et al. 2008. Impaired quality of life of patients with acromegaly: control of GH/IGF-I excess improves psychological subscale appearance. Eur J Endocrinol, 158:305-10.

Melmed S. 2001. Acromegaly and cancer: not a problem? J Clin Endocrinol Metab, 86:2929-34.

Melmed S. 2006. Acromegaly. N Engl J Med, 355:2558-73.

Melmed S, Casanueva FF, Cavagni T, et al. 2002. Consensus. Guidelines for acromegaly management. J Clin Endocrinol Metab, 87:4054-8.

Melmed S, Sternberg R, Cool D, et al. 2005. Clinical review: A critical analysis of pituitary tumor shrinkage during primary medical therapy in acromegaly. J Clin Endocrinol Metab, 90:4405-10.

Mestron A, Webb SM, Astorga R, et al. 2004. Epidemiology, clinical characteristics, outcome, morbidity and mortality in acromegaly based on the Spanish Acromegaly Registry (Registro Espanol de Acromegalia, REA). Eur J Endocrinol, 151:439-46.

Minniti G, Jaffrain-Rea ML, Osti M, et al. 2005. The long-term efficacy of conventional radiotherapy in patients with GH-secreting pituitary adenomas. Clin Endocrinol (Oxf), 62:210-16.

Morange I, De Boisvilliers F, Chanson P, et al. 1994. Slow release lanreotide treatment in acromegalic patients previously normalized by octreotide. $J$ Clin Endocrinol Metab, 79:145-51.

Murray RD, Kim K, Ren S-G. 2004. Central and peripheral actions of somatostatin on growth hormone-IGF-I axis. J Clin Invest, 114:349-56.

Neggers JCM, van Aken MO, Janssen JAM, et al. 2007. Long-term efficacy and safety of combined treatment of somatostatin analogs and pegvisomant in acromegaly. J Clin Endocrinol Metab, 92:4598-601.

Newman CB, Melmed S, Snyder PJ, et al. 1995. Safety and efficacy of long-term octreotide therapy of acromegaly: results of a multicenter trial in 103 patients-a clinical research center study. J Clin Endocrinol Metab, 80:2768-75.

Nomikos P, Buchfelder M, Fahlbusch R. 2005. The outcome of surgery in 668 patients with acromegaly using current criteria of biochemical 'cure'. Eur J Endocrinol, 152:379-87.

Olias G, Viollet C, Kusserow H, et al. 2004. Regulation and function of somatostatin receptors. $J$ Neurochem, 89:1057-91.

Orme S, McNally RJ, Cartwright RA, et al. 1998. Mortality and cancer incidence in acromegaly: a retrospective cohort study. J Clin Endocrinol Metab, 83:2730-4.

Patel YC. 1999. Somatostatin and its receptor family. Front Neuroendocrinol, 20:157-98.

Pereira AM, Biermaz NR, Roelfsema F, et al. 2005. Pharmacologic therapies for acromegaly. Treat Endocrinol, 4:43-53.

Pereira AM, Van Thiel SW, Lindner JR, et al. 2004. Increased prevalence of regurgitant valvular heart disease in acromegaly. J Clin Endocrinol Metab, 89:71-5.

Pokrajac A, Claridge AG, Abdoul Shakoor SK, et al. 2006. The octreotide test dose is not a reliable predictor of the subsequent response to somatostatin analogue therapy in patients with acromegaly. Eur $J$ Endocrinol, 154:267-74

Powell JS, Wardlaw SL, Post KD, et al. 2000. Outcome of radiotherapy for acromegaly using normalization of insulin-like growth factor I to define cure. J Clin Endocrinol Metab, 85:2068-71.

Razzore P, Colao A, Baldelli R, et al. 1999. Comparison of six months therapy with octreotide versus lanreotide in acromegalic patients: a retrospective study. Clin Endocrinol (Oxf), 51:159-64.

Reichlin S. 1983. Somatostatin. N Engl J Med, 309:1495-501.

Renehan AG, Shalet SM. 2002. Acromegaly and colorectal cancer: risk assessment should be based on population-based studies. J Clin Endocrinol Metab, 87:1909.

Ritchie CM, Atkinson AB, Kennedy AL, et al.1990. Ascertainment and natural history of treated acromegaly in Northern Ireland. Ulster Med J, 59:55-62.

Roberts BK, Ouyang DL, Shivanand PL, et al. 2007. Efficacy and safety of cyberknife radiosurgery for acromegaly. Pituitary, 10:19-25.

Roelfsema F, Biermasz NR, Pereira AM, et al. 2006. Nanomedicines in the treatment of acromegaly: focus on pegvisomant. Int J Nanomedicine, $1: 385-98$ 
Ronchi CL, Boschetti M, Degli Uberti EC, et al. 2007. Efficacy of a slow-release formulation of lanreotide (Autogel) $120 \mathrm{mg}$ in patients with acromegaly previously treated with octreotide long acting release (LAR): an open, multicentre longitudinal study. Clin Endocrinol (Oxf), 67:512-19.

Ronchi CL, Orsi E, Giavoli C, et al. 2003. Evaluation of insulin resistance in acromegalic patients before and after treatment with somatostatin analogues. $J$ Endocrinol Invest, 26:533-8.

Ronchi CL, Rizzo E, Lania AG, et al. 2008. Preliminary data on biochemical remission of acromegaly after somatostatin analogs withdrawal. Eur J Endocrinol, 158:19-25.

Rowles SV, Prieto L, Badia X, et al. 2005. Quality of life (QOL) in patients with acromegaly is severely impaired: use of a novel measure of QOL: acromegaly quality of life questionnaire. J Clin Endocrinol Metab, 90:3337-41.

Schade R, Andersohn F, Suisse S, et al. 2007. Dopamine agonists and the risk of cardiac-valve regurgitation. $N$ Engl J Med, 356:29-38.

Schloffer H. 1907. Erfolgreiche Operation eines Hypophysentumors auf nasalem Wege. Wien Klin Wochenschr, 20:621-4.

Schreiber I, Buchfelder M, Droste M, et al. 2007. Treatment of acromegaly with the GH receptor antagonist pegvisomant in clinical practice: safety and efficacy evaluation from the German Pegvisomant Observational Study. Eur J Endocrinol, 156:75-82.

Serri O, Brazeau P, Kachra Z, et al.1992. Octreotide inhibits insulin-like growth factor-I hepatic gene expression in hypophysectomized rat: evidence for a direct and indirect mechanism of action. Endocrinology, 130:1816-21.

Sheehan JP, Niranjan A, Sheehan JM, et al. 2005. Stereotactic radiosurgery for pituitary adenomas: an intermediate review of its safety, efficacy, and the role in the neurosurgical treatment armamentarium. J Neurosurg, 102:678-91.

Shimon I, Cohen ZR, Ram Z, et al. 2001. Transsphenoidal surgery for acromegaly: endocrinological follow-up of 98 patients. Neurosurgery, 48:1239-43.

Sjogren K, Liu JL, Blad K, et al. 1999. Liver-derived insulin-like growth factor I (IGF-I) is the principle source of IGF-I in blood but it is not required for postnatal body growth in mice. Proc Natl Acad Sci USA, 96:7088-92.

Sonino N, Scarpa E, Paoletta A, et al. 1999. Slow-release lanreotide treatment in acromegaly: effects on quality of life. Psychother Psychosom, 68:165-7.

Sonksen PH, Greenwood FC, Ellis JP, et al. 1967. Changes of carbohydrate tolerance in acromegaly with progress of the disease and in response to treatment. J Clin Endocrinol Metab, 27:1418-30.

Steffin B, Gutt B, Bidlingmaier M, et al. 2006. Effects of the long-acting somatostatin analogue Lanreotide Autogel on glucose tolerance and insulin resistance in acromegaly. Eur J Endocrinol, 155:73-8.

Stevenaert A, Beckers A. 1996. Presurgical octreotide treatment in acromegaly. Metabolism, 45(Suppl 1):72-4.

Suliman M, Jenkins R, Ross R, et al. 1999. Long-term treatment of acromegaly with the somatostatin analogue SR-lanreotide. $J$ Endocrinol Invest, 22:409-18.

Swaeringen B, Barker FG, Katznelson L, et al. 1998. Long-term mortality after transsphenoidal surgery and adjunctive therapy for acromegaly. $J$ Clin Endocrinol Metab, 83:3419-26.

Taboada GF, Luque RM, Neto LV, et al. 2008. Quantitative analysis of somatostatin receptor subtypes (1-5) gene expression levels in somatotropinomas and correlation to in vivo hormonal and tumor volume responses to treatment with octreotide LAR. Eur J Endocrinol, 158:295-303.
Thalassinos NC, Tsagarakis S, Ioannides G, et al. 1998. Megavoltage pituitary irradiation lowers, but seldom leads to safe GH levels in acromegaly: a long-term follow-up study. Eur J Endocrinol, 138:160-3.

Thomale UW, Stover JF, Unterberg AW. 2005. The use of neuronavigation in transnasal transsphenoidal pituitary surgery. Zentralbl Neurochir. 66:126-32.

Trainer PJ, Drake WM, Katznelson L, et al. 2000. Treatment of acromegaly with the growth hormone-receptor antagonist pegvisomant. $N$ Engl $J$ Med, 342:1171-7.

Turner HE, Vadivale A, Keenan J, Wass JA. 1999. A comparison of lanreotide and octreotide LAR for treatment of acromegaly. Clin Endocrinol (Oxf), 51:275-280.

Valéry C, Paternostre M, Robert B, et al. 2003. Biomimetic organization: Octapeptide self-assembly into nanotubes of viral capsid-like dimension. Proc Natl Acad Sci USA, 100:10258-62.

Valéry C, Pouget E, Pandit A, et al. 2008. Molecular origin of the selfassembly of lanreotide into nanotubes: a mutational approach. Biophys $J, 94: 1782-95$.

Van den Berg G, Frolich M, Veldhuis JD, et al. 1994. Growth hormone secretion in recently operated acromegalic patients. J Clin Endocrinol Metab, 79:1706-15.

Van den Berg G, Pincus SM, Frolich M, et al.1998. Reduced disorderliness of growth hormone release in biochemically inactive acromegaly after pituitary surgery. Eur J Endocrinol, 138:164-9.

Van der Hoek J, Lamberts SW, Hofland LJ. 2004. The role of somatostatin analogs in Cushing's disease. Pituitary, 7:257-64.

Van der Hoek J, van der Lely AJ, Feelders RA, et al. 2005. The somatostatin analogue SOM230, compared with octreotide, induces differential effects in several metabolic pathways in acromegalic patients. Clin Endocrinol (Oxf), 63:176-84.

Van der Lely AJ, Hutson RK, Trainer PJ, et al. 2001. Long-term treatment of acromegaly with pegvisomant, a growth hormone receptor antagonist. Lancet, 358:1754-9.

Van Thiel SW, Bax JJ, Biermasz NR, et al. 2005. Persistent diastolic dysfunction despite successful long-term octreotide treatment in acromegaly. Eur J Endocrinol, 153:231-8.

Van Thiel SW, Romijn JA, Biermasz NR, et al. 2004. Octreotide long-acting repeatable and lanreotide Autogel are equally effective in controlling growth hormone secretion in acromegalic patients. Eur J Endocrinol, 150:489-95.

Verhelst JA, Pedroncelli AM, Abs R, et al. 2000. Slow-release lanreotide in the treatment of acromegaly: a study in 66 patients. Eur J Endocrinol, 143:577-84

Wasko R, Jankowska A, Kotwicka M, et al. 2003. Effects of treatment with somatostatin analogues on the occurrence of apoptosis in somatotropinomas. Neuro Endocrinol Lett, 24:334-8.

Wass JA, 2003. Radiotherapy in acromegaly: a protagonist's viewpoint. Clin Endocrinol (Oxf), 58:128-31.

Wass JA, Cudworth AG, Bottazzo GF, et al. 1980. An assessment of glucose intolerance in acromegaly and its response to medical treatment. Clin Endocrinol (Oxf), 12:53-59.

Wright AD, Hill DM, Lowy C, et al. 1970. Mortality in acromegaly. $Q J$ Med, 39:1-16.

Zatelli MC, Ambrosio MR, Bondanelli M, et al. 2007. Control of pituitary adenoma cell proliferation by somatostatin analogs, dopamine agonists and novel chimeric compounds. Eur J Endocrinol, 156:S29-S35. 
